\title{
Selection of Cellulolytic Fungi Isolated from Diverse Substrates
}

\author{
Mônica Caramez Triches Damaso ${ }^{1,2^{*}}$, Selma da Costa Terzi ${ }^{1}$, Antonio Xavier Farias ${ }^{1}$, Ana \\ Carolina Pereira de Oliveira $^{3}$, Marcelo Elias Fraga ${ }^{4}$ and Sonia Couri ${ }^{1}$ \\ ${ }^{1}$ Embrapa Agroindústria de Alimentos; Av. das Américas, 29501; 23020-470; Rio de Janeiro - RJ - Brasil. \\ ${ }^{2}$ Embrapa Agroenergia; Parque Estação Biológica - PqEB s/n; 70770-901; Brasília - DF - Brasil. ${ }^{3}$ Universidade \\ Estadual do Norte Fluminense; Ensino à Distância de Biologia; Campos dos Goytacazes - RJ - Brasil. \\ ${ }^{4}$ Universidade Federal Rural do Rio de Janeiro; BR 465 km 7; Seropédica - RJ - Brasil
}

\begin{abstract}
The aim of the present work was to select filamentous fungi isolated from diverse substrates to obtain the strains with potential to produce the hydrolytic enzymes. From a total of 215 strains, seven strains from the soils, six from the plants and one from sugarcane bagasse were selected and identified as belonging to the Trichoderma, Penicillium and Aspergillus genera. The best hydrolytic activities obtained by semi-solid fermentation using these strains were approximately: 35; 1; 160; 170 and $120 \mathrm{U} / \mathrm{gdm}$ (CMCase, FPase, $\beta$-glucosidase, xylanase and polygalacturonase, respectively), demonstrating their potential to synthesize the enzymes compared with the results reported in the literature.
\end{abstract}

Key words: cellulases, semi-solid fermentation, filamentous fungi, hydrolytic enzymes

\section{INTRODUCTION}

Fungi are the most important microorganisms for the decomposition of organic matter due to their degradation abilities. When large amounts of extracellular enzymes, essential for the degradation of substrates, such as lignocellulose, are produced, the decomposition of this organic matter can occur (Gomes 2007).

Cellulases produced by the filamentous fungi, yeasts and bacteria are implicated in the degradation of cellulose fibers to soluble sugars such as glucose, cellobiose and other oligomers. Microorganisms excreting cellulases play an important role in the nature, due to their ability to decompose lignocellulosic residues, establishing a key link in the carbon cycle (Zhang et al. 2006).
Studies have been carried out with endophytic fungi that present a large variety of interactions and associations to their hosts, including mutualism, commensalism and antagonism (Stone et al. 2000), as well as, secondary metabolite production related to the biological control of insects and diseases (Wichlow et al. 2005). However, taking into account the mechanisms of these above mentioned interactions and associations, more studies related to the production of cellulolytic enzymes should be carried out. Most of the commercial cellulases (including $\beta$ glucosidase) have been produced from the Trichoderma, Penicillium and Aspergillus genera (Kirk et al. 2002; Cherry and Fidantsef 2003; Ruegger and Tank-Tornisielo 2004). Nowadays, T.reesei is the main focus of research and

*Author for correspondence: mctdamaso@gmail.com 
development studies for cellulases production. In the 1980s, cellulases from Trichoderma were used in the animal feed industry.

Since then, the production of this enzyme has increased significantly and today its production is around $20 \%$ of all the enzymes produced in the world. According to Lynd et al. (2002), the cellulolytic complex of the fungi is well defined by three enzymes: endoglucanase $(1,4-\beta-\mathrm{D}-$ glucan glucanohydrolase EC 3.2.1.4), cellobiohydrolase $(1,4-\beta$-glucan cellobiohydrolase EC 3.2.1.91) and $\beta$-glucosidase ( $\beta-D-$ glucosidase glucohydrolase EC 3.2.1.21).

The trading profit of these enzymes for the future of energy agribusiness, mainly in terms of ethanol production from biomass, essentially depends on the economic production. Thus, the selection of the microorganisms with high enzyme synthesis ability is required, as well as the need to be germfree, stable, easily preserved and produced. Therefore, the aim of this study was to select the filamentous fungi isolated from the soils, endophytic environment, sugarcane bagasse and poultry litter by evaluating the activity of the extracellular enzymes obtained by semi-solid state fermentation.

\section{MATERIALS AND METHODS}

\section{Isolation and conservation of isolated samples}

A total of 215 fungi samples isolated from the soils, sugarcane bagasse, plants and strains pertaining to the Brazilian Agricultural Research Corporation (Embrapa) Cultures Collection and Federal Rural University of Rio de Janeiro Mycology and Mycotoxicology Centre, were studied. Fungi were isolated by serial dilution on PDA medium (Potato Dextrose Agar) with the addition of chloramphenicol. Subsequently they were stored on MEA (Malt Extract Agar) at $4^{\circ} \mathrm{C}$. The isolations were performed in Erlenmeyer flasks by the re-suspension of five grams of the sample in $45 \mathrm{~mL}$ peptone solution $(0.1 \%)$ containing $0.1 \%$ Tween 80 , followed by $30 \mathrm{~min}$ shaking at $150 \mathrm{rpm}$ (Gomes et al. 2001; Markovina et al. 2005). The identification of the species was carried out on selective media for each group of fungus and based on the morphological studies (Raper and Fennell, 1965; Domsch et al. 1980; Klich and Pitt 1988; Barnett et al. 1999; Davel and Rouxel 2000; Pitt 2000; Samson et al 2000; Klich 2002; Watanabe 2002; Samson and Frisvad 2004).

\section{Characterization of the cellulolytic isolated samples}

Cellulose degradation ability was evaluated on the basic medium (modified by Couri and Farias, 1995) with carboxymethylcellulose, sugarcane bagasse or "avicel" as the carbon source. Each isolated fungus was inoculated in the basic medium, distributed on Petri dishes and incubated at 25 or $32^{\circ} \mathrm{C}$ and thereafter $10 \mathrm{~mL}$ of Congo Red buffer (0.1 M Tris $\mathrm{HCl}, \mathrm{pH} 8)$ was added. After15 min, the solution was discarded and the cultures were washed with $5.0 \mathrm{~mL} 0.5 \mathrm{M} \mathrm{NaCl}$ in the same buffer, and the hydrolysis halos were measured (Teather and Wood 1982).

\section{Selection of the strains}

The selection of the filamentous fungi as good producers of cellulolytic enzymes was carried out as follows: 1) measurement of the diameter of the cultivated colonies on the basic medium with carboxymethylcellulose as the carbon source in the Petri dishes; 2) estimation of enzymatic index with the Congo Red stain solution. At the places where the carboxymethylcellulose substrate was hydrolyzed, a translucent halo was displayed and the enzymatic index was evaluated by the ratio between the diameter of the halo and the diameter of the colony. Strains presenting indexes near or greater than 1 (one) were selected; 3) production of the enzyme by semi-solid fermentation using the strains selected from stages 1 and 2 (modified by Damaso et al. 2008).

\section{Semi-solid fermentation}

Tests were carried out in duplicate in $500 \mathrm{~mL}$ Erlenmeyer flasks containing $40 \mathrm{~g}$ of medium. The fermentation medium was made up of $100 \mathrm{~g}$ of wheat bran and $60 \mathrm{~mL}$ of $0.91 \%\left(\mathrm{NH}_{4}\right)_{2} \mathrm{SO}_{4}$ solution in $0.1 \mathrm{~N} \mathrm{HCl}$, sterilized for $15 \mathrm{~min}$ at 1 atm (Couri et al. 2000). Sterilized fermentation medium was inoculated with $10^{7}$ conidia/g of medium. Fermentation occurred at $32^{\circ} \mathrm{C}$ in an incubation chamber. After $48 \mathrm{~h}$, enzymes were extracted with $2.5 \mathrm{~mL} 100 \mathrm{mM}$ acetate buffer per gram of semi-solid fermentation medium as described by Couri et al. (2006).

\section{Enzymatic activity}

The cellulase activity was measured using the filter paper activity (FPase) assay. This method measured the release of reducing sugars produced in $60 \mathrm{~min}$ from a mixture of enzyme $(1.0 \mathrm{~mL})$ and of sodium citrate buffer $(2.0 \mathrm{~mL}, 0.05 \mathrm{M}, \mathrm{pH} 4.8)$ 
in the presence of a $1 \mathrm{~cm} \times 6 \mathrm{~cm}$ filter paper strip and incubated at $50^{\circ} \mathrm{C}$ (Wood and GarciaCampayo, 1990). The endo 1,4 $\beta$-glucanase activity was determined by measuring the reducing sugars released at $50^{\circ} \mathrm{C}$ after $10 \mathrm{~min}$ of reaction using a mixture of $0.25 \mathrm{~mL}$ of $4 \%$ carboxymethylcellulose prepared in sodium citrate buffer (0.05M, pH 4.8) and $0.25 \mathrm{~mL}$ of the enzyme (Novo Industri, 1978). The xylanase activity was measured by reacting $2.0 \mathrm{~mL}$ of xylan solution $(1 \% \mathrm{w} / \mathrm{v}$, sodium acetate $0.2 \mathrm{M}, \mathrm{pH} 5.0)$ and 1.0 $\mathrm{mL}$ of the enzyme at $50^{\circ} \mathrm{C}$ after $30 \mathrm{~min}$ (Gomes et al. 1992). The polygalacturonase activity was determined using $4.0 \mathrm{~mL}$ of polygalacturonic acid $(0.25 \%$, sodium acetate $0.2 \mathrm{M}, \mathrm{pH} 4.5)$ and $0.1 \mathrm{~mL}$ of the enzyme at $35{ }^{\circ} \mathrm{C}$. The activity of $\beta$ glucosidase was determined using cellobiose as substrate $(15 \mathrm{mM}$, sodium citrate buffer, $0.05 \mathrm{M}$, pH 4.8) (Wood and Garcia-Campayo 1990).The released reducing sugars were measured after 30 min of reaction (Couri et al. 2000). For all the activities, the reducing sugars liberated during the enzymatic assays were quantified by the DNS method (Miller, 1959), except those of $\beta$ glucosidase, which were quantified using an analytical kit based on the enzymes: glucose oxidase and peroxidase. For all the activities, one enzyme unit (U) was defined as the amount of biocatalyst that liberated one micromole of the corresponding monosaccharide per minute, under the assay conditions used. All the enzymatic activities were determined at least in duplicate and represented as $\mathrm{U}$ per gram $(\mathrm{gdm})$ of dry fermentation medium and by $\mathrm{U} / \mathrm{mL}$.

\section{RESULTS AND DISCUSSION}

From the 215 strains tested by Congo Red stain, 14 samples that presented an enzymatic index over one were selected (results not shown). Table 1 shows the selected strains: seven from the soils, six from the plants (endophytic) and one from sugarcane bagasse. The Rural Federal University of Rio de Janeiro Mycology and Mycotoxicology Centre classified them as belonging to the Trichoderma, Penicillium and Aspergillus genera. The mutant A. niger 3T5B8 from Embrapa Food Technology Cultures Collection used as standard strain was previously selected as a pectinolytic enzyme producer by semi-solid fermentation (Table 1) (Couri and Farias, 1995).

Table 1 - Fungi isolated from diverse substrates.

\begin{tabular}{ccc}
\hline Isolates & Substrate & Fungi \\
\hline $1^{*}$ & Black pepper & Aspergillus niger 3T5B8 mutant \\
2 & Soil & Trichoderma \\
3 & Soil & Trichoderma \\
4 & Soil & Trichoderma \\
5 & Soil & Trichoderma \\
6 & Soil & Trichoderma \\
7 & Sugarcane bagasse & Penicillium \\
8 & Soil & Trichoderma \\
9 & Soil & Aspergillus \\
10 & Plant & Aspergillus \\
11 & Plant & Aspergillus \\
12 & Plant & Aspergillus \\
13 & Plant & Aspergillus \\
14 & Plant & Aspergillus \\
15 & Plant & Aspergillus \\
\hline
\end{tabular}

The isolate 1 corresponds to the standard strain

Figures 1, 2, 3, 4 and 5 show the production ability of the hydrolytic enzyme "pool" (carboxymethylcellulase, FPase, $\beta$-glucosidase, xylanase and polygalacturonase).In relation to the standard strain $(2.1 \mathrm{U} / \mathrm{gdm}$ and $8.6 \mathrm{U} / \mathrm{mL})$, as well as, under semi-solid fermentation conditions, the strains $7,11,13,14$ and 15 produced CMCase activity as following: $12.3 ; 11.7 ; 12.4 ; 13.7$ and $15.1 \mathrm{U} / \mathrm{mL}$ or $31.0 ; 29.3 ; 31.3 ; 34.4$ and $37.8 \mathrm{U} / \mathrm{gdm}$, respectively. These strains were the best producers of CMCase (Fig. 1). Strain 7 belonged to Penicillium genus and 11, 13, 14 and 15 belonged to the Aspergillus genus. 


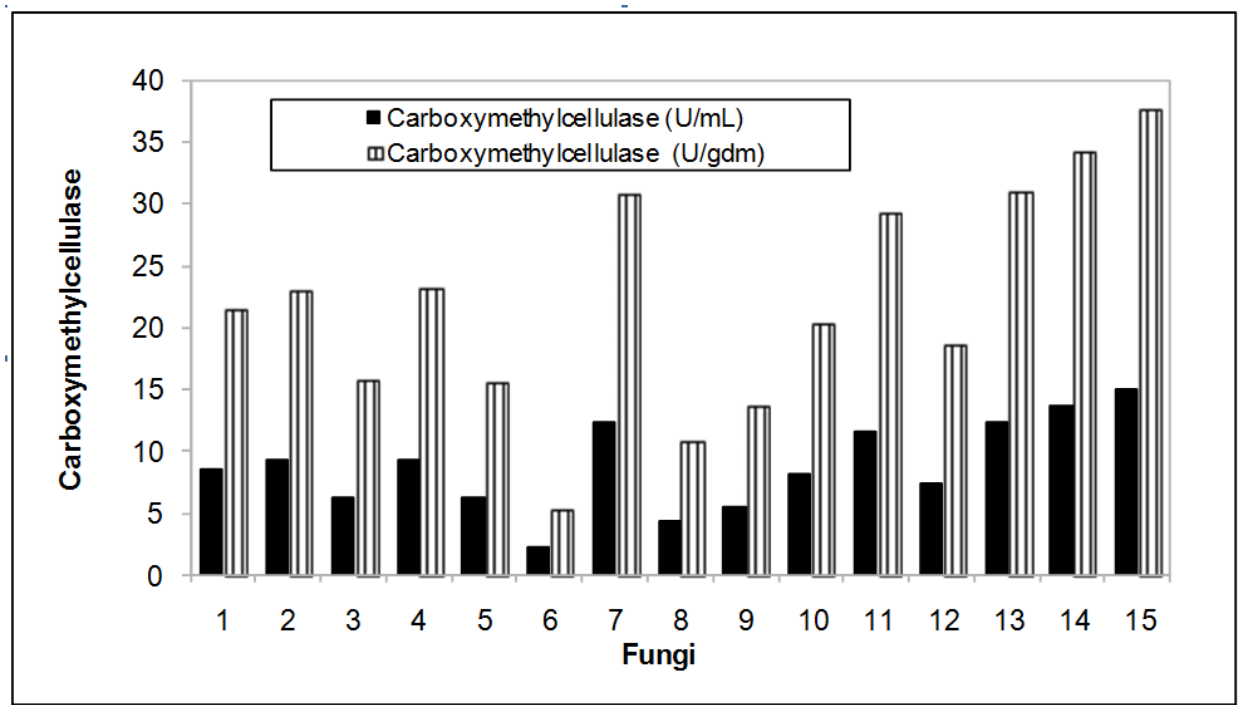

Figure 1 - Production of carboxymethylcellulase (U/gdm and U/mL) on semi-solid fermentation by filamentous fungi isolated from diverse substrates according to Table 1.

In terms of FPase production, only strain $11(0.45$ $\mathrm{U} / \mathrm{mL} ; 1.13 \mathrm{U} / \mathrm{gdm})$ was better than the standard strain $1(0.41 \mathrm{U} / \mathrm{mL} ; 1.03 \mathrm{U} / \mathrm{gdm})$, both from Aspergillus genus (Fig. 2). According to data from literature, the fungi from the Trichoderma genus have been classified as the best producers of this enzyme; however, in this study the Aspergillus strains were the best (Fig. 2, Table 1).

The optimization of FPase production under semisolid fermentation conditions from $T$. reesei $\mathrm{QM}$ 9414 and MCG 77 mutant strains, using rice bran as substrate was demonstrated by Latifian et al. (2007). The best results obtained after eight days of fermentation were as follows: $2.31 \mathrm{U} / \mathrm{gdm}$ for the MCG 77 strain at $\mathrm{pH} 5.0,70 \%$ humidity and $30^{\circ} \mathrm{C}$, while for the QM 9414 strain, the best activity was $1.16 \mathrm{U} / \mathrm{gdm}$ at $\mathrm{pH} 2.5,55 \%$ humidity and $25^{\circ} \mathrm{C}$. The result obtained with strain 11 could be considered good in comparison to those from Latifian et al. (2007), taking into account the fermentation time and that strain 11 was a wild strain. Sukumaran et al. (2009) demonstrated the production of a cellulolytic "pool" (FPase, carboxymethylcellulase and $\beta$-glucosidase) by semi-solid fermentation using wheat bran and the strains from $T$. reeseiRUTC30 and Aspergillus niger MTCC7956.

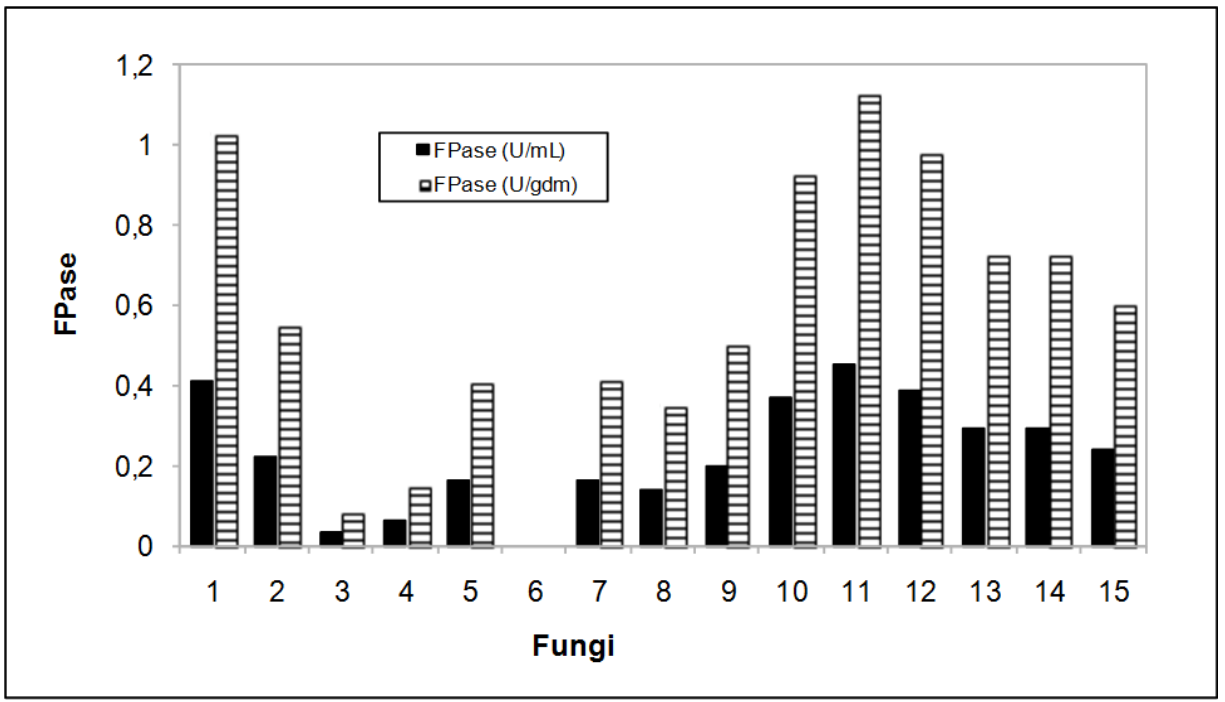

Figure 2 - Production of FPase (U/gdm and U/mL) on semi-solid fermentation by filamentous fungi isolated from diverse substrates according to Table 1. 
The results of the FPase, CMCase and $\beta$ glucosidase activities were $1.14 \mathrm{U} / \mathrm{mL}, 14.91$ $\mathrm{U} / \mathrm{mL}$, and $0.22 \mathrm{U} / \mathrm{mL}$, respectively, for $T$. reesei RUT C 30 strain and the results for the A. niger were $0.24,6.77$ and $2.84 \mathrm{U} / \mathrm{mL}$, respectively. In comparison to these results, the following strains selected for this study (Table 1, Fig. 3) demonstrated their potentially as good enzyme synthesizers: 4 (62.0 U/mL; Trichoderma), 7 (67.0 $\mathrm{U} / \mathrm{mL} ;$ Penicillium $)$ and $11 \quad(63.0 \mathrm{U} / \mathrm{mL}$; Aspergillus).

Gao et al. (2008) isolated a thermoacidophilic
A. terreus M11 for the production of cellulases. Different carbon and nitrogen sources as well as yeast extract concentrations by semi-solid fermentation in conical flasks were tested. Results obtained for CMCase and FPase with wheat bran were higher $(315 \mathrm{U} / \mathrm{gdm}$ and $166 \mathrm{U} / \mathrm{gdm}$, respectively) than those obtained by the strains isolated in the present study; however, the $\beta$ glucosidase results $(79 \mathrm{U} / \mathrm{gms})$ were lower than the best producing strains in the present study: 4 (155 U/gdm), 7 (168 U/gdm) and 11 (158 U/gdm) (Fig. 3).

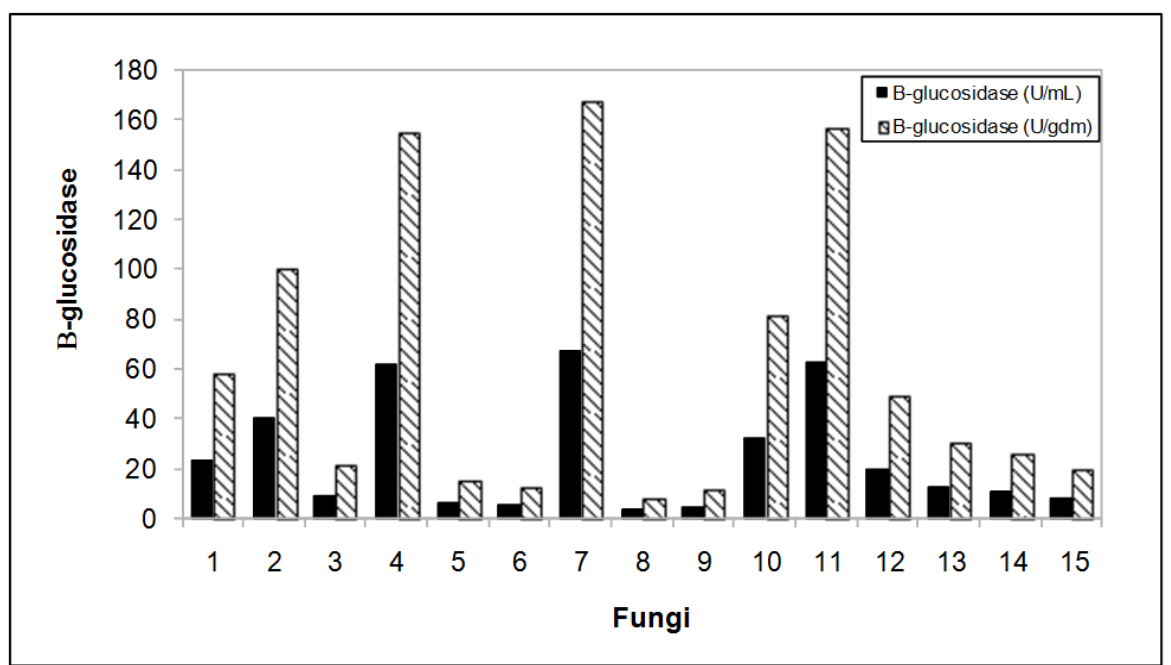

Figure 3 - Production of $\beta$-glucosidase (U/gdm and $\mathrm{U} / \mathrm{mL}$ ) on semi-solid fermentation by filamentous fungi isolated from diverse substrates according to Table 1.

Synergism is fundamental for the total hydrolysis of various lignocellulosic substances: FPase and carboxymethylcellulase hydrolyze the polymeric chain of cellulose macromolecules and $\beta$ glucosidase hydrolyzes cellobiose coming from the action of the latter two into glucose.

Ahamed and Vermette (2008) studied the productions of CMCase and FPase under submerged fermentation by stirred tank bioreactor. A strategy based on the mixed cultures of $T$. reesei and $A$. niger was used in order to increase the enzyme production compared to A. niger alone. This strategy proved to be beneficial as the following results were obtained: FPase $-7.1 \mathrm{U} / \mathrm{mL}$ and CMCase $-4.7 \mathrm{U} / \mathrm{mL}$, while the monoculture resulted in 3.4 and $2.9 \mathrm{U} / \mathrm{mL}$, respectively. Comparing these results to those in the present study, the FPase values from Ahamed and Vermette (2008) presented better results, either as separate mixtures or as a single colony (Fig. 2).
However, CMcase (Fig. 1) in the present study showed a value 3 times greater $(15 \mathrm{U} / \mathrm{mL})$ for the endophytic strain of Aspergillus (strain 15).

Damaso et al. (2002) obtained a xylanase activity of $500 \mathrm{U} / \mathrm{mL}$ with Thermomyces lanuginosus IOC4145 on corn cobs by semi-solid fermentation after $96 \mathrm{~h}$ of production. Xylanase presented 167 and $178 \mathrm{U} / \mathrm{mL}$ for the best strains (2, 4 and 11) (Fig. 4). However, the aim of this study was the selection of microorganisms and production time (48 h), in other words, in half the time used by Damaso et al. (2002).

Taragano et al. (1997) studied an A. niger strain using wheat bran as substrate and the maximum polygalacturonase $(\mathrm{PG})$ activity obtained was 30 U/mL. The strains 1, 4, 7, 10, 13, 14 and 15 (Fig. 5) presented the best performances, specially the mutant A.niger 3T5B8 with PG activity of around $73 \mathrm{U} / \mathrm{mL}$. 


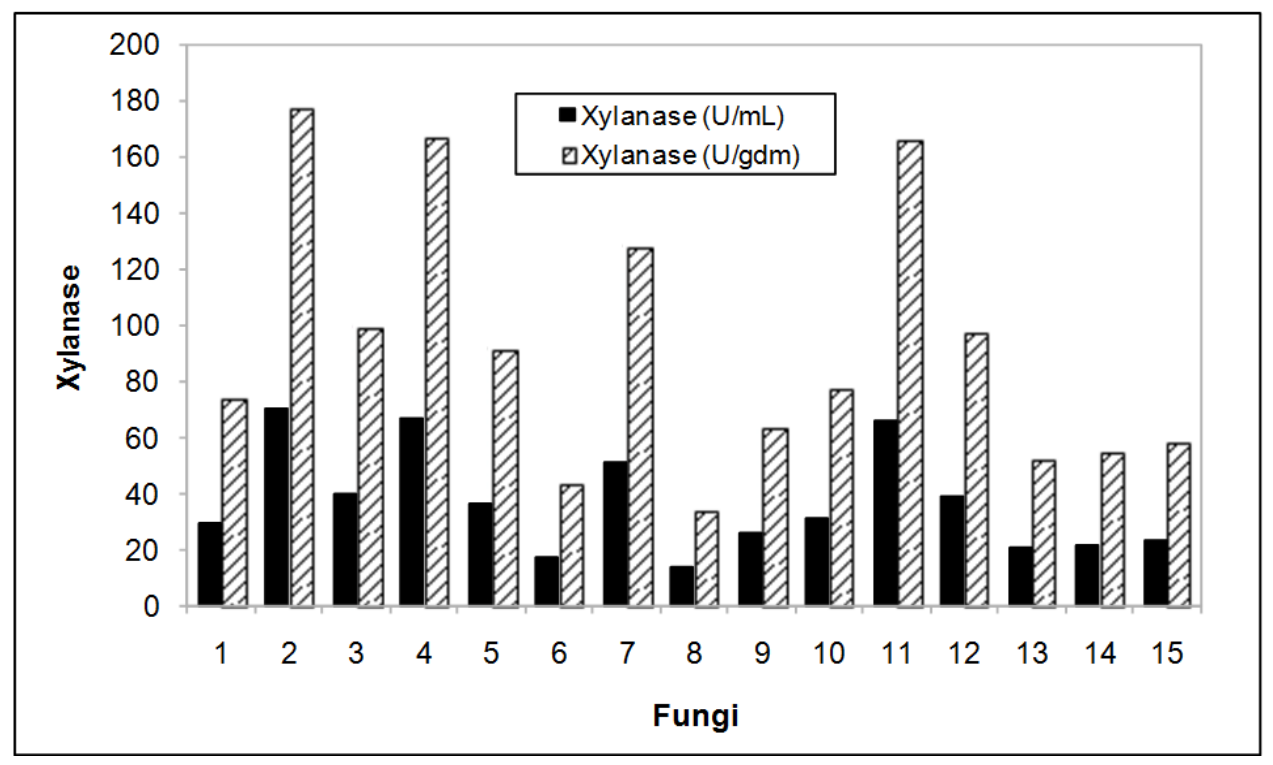

Figure 4 - Production of Xylanase (U/gdm and U/mL) on semi-solid fermentation by filamentous fungi isolated from diverse substrates according to Table 1.

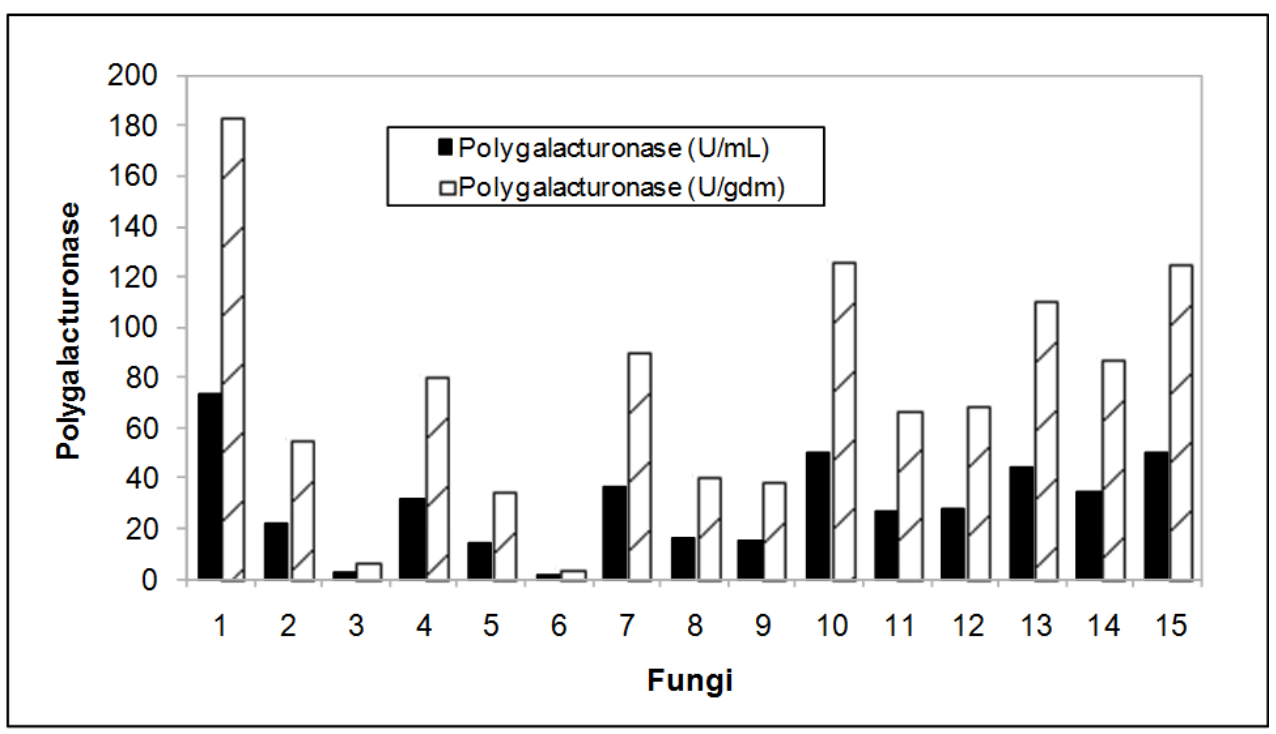

Figure 5 - Production of Polygalacturonase (U/gdm and U/mL) on semi-solid fermentation by filamentous fungi isolated from diverse substrates according to Table 1.

Martin et al. (2010) isolated 34 thermophilic and thermotolerant fungi strains and the best PG production was shown by Thermomucor indicaeseudaticae. The highest PG activity $(120 \mathrm{U} / \mathrm{mL})$ was obtained after 12 days of semi-solid state fermentation with wheat bran and orange bagasse $(1: 1)$ in $70 \%$ initial humidity at $45^{\circ} \mathrm{C}$. This result in terms of enzymatic activity was better than those obtained by the strains evaluated in this study; however, if the time of production $(48 \mathrm{~h})$ was taken into consideration, the productivity of the standard strain (1) and the isolated strains 4, 7, 10, 13, 14 and 15 were higher than that of the Thermomucor.

Strains of Trichoderma have been extensively studied in terms of cellulolytic enzymes production. This genus of fungi has shown many remarkable results, mainly in terms of FPase activity; however, for $\beta$-glucosidase production, the genus was considered inappropriate. Strains isolated for this study, especially 4,7 and 11 
(Table 1) presented favorable cellulase production and use in enzymatic hydrolysis to obtain the fermentable sugars.

From the 215 strains tested by Congo Red stain, the Penicillium endophytic strain (7) isolated from sugarcane bagasse and a single one from Aspergillus (11) isolated from a parasitic plant were selected for producing the extracts with enzymatic activity levels consistent with the standard strain, as well as, those reported in the literature. The selection of the cellulolytic fungi by fermentation tests was corroborated.

\section{REFERENCES}

Ahamed A, Vermette P. Enhanced enzyme production from mixed cultures of Trichoderma reesei RUT-C30 and Aspergillus niger LMA grown as fed batch in a stirred tank bioreactor. Biochem. Engineer. J. 2008; 42: 41-46.

Barnett HL, Hunter BB. Illustrated genera of imperfect fungi. 4 th ed. Saint Paul MN: APS Press, 1989.

Berner RA. The long-term carbon cycle, fossil fuels and atmospheric composition. Nature 2003; 426: 323326.

Cherrry JR, Fidantsef AL. Directed evolution of industrial enzymes: an update. Curr. Opin. Biotechnol. 2003; 14: 438-43.

Corabi-Adell C, Lucon CMM, Koike CM. Biodiversidade do gênero Trichoderma no estado de São Paulo - Aspecto enzimático e potencial biocontrolador. Arq. Inst. Biol. 2002; 69: 188-191.

Couri S, Farias AX. Genetic manipulation of Aspergillus niger for increased synthesis of pectinolytic enzymes. Rev. Microbiol. 1995; 26: 314317.

Couri S, Terzi SC, Pinto GAS, Freitas, SP, Costa, ACA. Hydrolytic enzyme production in solid-state fermentation by Aspergillus niger 3T5B8. Process Biochem. 1995; 36: 255-261.

Damaso MCT, Andrade CMMC, Pereira JRN. Production and properties of the cellulase-free xylanase from Thermomyces lanuginosus IOC-4145. Braz. J. Microbiol. 2002; 33: 333-338.

Damaso MCT, Passianoto MA, Freitas SC, Freire DMG, Lago RCA, Couri S. Utilization of agroindustrial residues for lipase production by solidstate fermentation. Braz. J. Microbiol. 2008; 39: 1-6.

Davet P, Rouxel F. Detection and isolation of soil fungi. Plymouth, UK: INRA Science Publishers; 2002.

Domsch KH, Gams W, Anderson TH. Compedium of soil fungi. London: Academic Press; 1993.
Gao J, Weng H, Zhu D, Yuan M, Guan F, Xu Y. Production and characterization of cellulolytic enzymes from the thermoacidophilic fungal Aspergillus terreus M11 under solid-state cultivation of corn stover. Bioresource Technol. 2008; 99: 76237629.

Gomes DNF. Diversidade e potencial biotenológico de fungos filamentosos isolados do manguezal Barras das Jangadas, Jaboatão do Guararapes, Pernambuco. \{Dissertação de Mestrado]. Recife, Brasil: Universidade Federal de Pernambuco; 2007.

Gomes I, Gomes J, Steiner W, Esterbauer H. Production of cellulase and xylanase by a wild strain of Trichoderma viride. Appl. Microbiol. Biotechnol. 2002; 36: 701-707.

Gomes NCM, Heuer H, Schonfeld J. Bacterial diversity of the rhizosphere of maize (Zea Mays) grow in tropical soil studied by temperature gradient gel electrophoresis. Plant Soil 2001; 232: 167-180.

Kirk O, Borchert TV, Fuglasang CC. Industrial enzyme applications. Curr. Opin. Biotechnol. 2001: 13: 345351.

Klich MA. Identification of common Aspergillus species. Utrecht, Netherlands: CBS; 2002.

Klich MA, Pitt JI. A laboratory guide to common Aspergillus species and their teleomorphs. North Ryde, Australia: CSIRO; 1988.

Lakshmi GS, Rao CS, Rao RS, Hobbs PJ, Prakasham RS. Enhanced production of xylanase by a new isolated Aspergillus terreus under solid state fermentation using palm industrial waste: A statistical optimization. Biochem. Eng. J. 2009; 48: 51-57.

Latifian M, Hamidi-esfahani Z, Barzegar M. Evaluation of culture conditions for cellulase production by two Trichoderma reesei mutants under solid-state fermentation conditions. Bioresource Technol 2007; 98: 3634-3637.

Lynd LR, Weimer PJ, Zyl WHV, Pretorius IS. Microbial cellulose utilization: fundamentals and biotechnolgy. Microbiol. Mol. Biol. R. 2002; 66: 506577.

Markovina A, Pitt JI, Hocking AD. Diversity of the Trichocomaceae in the Katandra Nature Reserve, Central Coast, NSW, Australia. Mycol. Res. 2005; 109: 964-973.

Martin N, Guez MAU, Sette LD, Da Silva R, Gomes E. Pectinase production by a Brazilian thermophilic fungus Thermomucor indicae-seudaticae N31 in solid - state and submerged fermentation. Microbiology 2010; 79: 306-313.

Miller GL. Use of dinitrosalicylic acid reagent for determination of reducing sugar. Anal. Biochem. 1959; 31: 426-428.

Novo Industri S.A. (Dinamarca), Celulase determination: Division Enzymes, N. AF149/5, GB. 1978. 
Oliveira JA. Efeito do tratamento fungico em sementes e no controle de tombamento de plântulas de pepino (Cucumis sativus L.) e pimentão (Capsicum annuum L.). [Dissertação de Mestrado]. Minas Gerais, Brasil: Universidade Federal de Lavras; 1991.

Pitt JI. A laboratory guide to common Penicillium species. Australia: Food Science Australia a Joint Venture of CSIRO and AFISC; 2000.

Raper KB, Fennell DI. The genus Aspergillus. Baltimore: Williams \& Wilkins; 1965.

Ruegger MJS, Tauk-tornisielo SM. Atividade da celulose de fungos isolados do solo da Estação Ecológica de Juréia-Itatins, SP, Brasil. Rev. Brasil. Bot. 2004; 27: 205-211.

Samson RA, Hoekstra ES, Frisvad JC, Filtenborg O Introduction to food and airborne fungi. $6^{\text {th }}$ ed. Baarn, The Netherlands: CBS; 2000.

Samson RA, Frisvad JC. Penicillium subgenus Penicillium: new taxonomic schemes, mycotoxins and other extrolites. Stud Mycol. 2004; 49: 1-251.

Stone JK, Bacon CW, White JF. An overview of endophytic microbes: endophytism defined. In: Bacon CW, White JF Microbial Endophytes. New York: Marcel Dekker: 2002.

Sukumaran RK, Singhania RR, Mathew GW, Pandey A. Cellulase production using biomass feed stock and its application in lignocellulose saccharification for bio-ethanol production. Renew. Energ. 2009; 34: 421424.
Taragano V, Sanchez VE, Pilosof AMR. Combined effect of water activity depression and glucose addition on pectinases and protease production by Aspergillus niger. Biotechnol Lett. 1997; 19: 223226.

Teather RM, Wood PJ. Use of congo redpolysaccharide interactions in enumeration and characterization of cellulolytic bacteria from the bovine rumen. App. Environ. Microbiol. 1982; 43: 777-780.

Watanabe T. Pictorial atlas of soil and seed fungi morphologies of cultured fungi and key to species. 2 ed. Londom, UK: CRC Press; 2002.

Wichlow DT, Roth S, Deyrup ST, Gloer JB. A protective endophyte of maize: Acremonium zeae antibiotics inhibitory to Aspergillus flavus and Fusarium verticillioides. Mycol. Res. 2005; 109: 610-618.

Wood TM, Garcia-Campayo V. Enzymology of cellulose degradation. Biodegradation 1990; 1: 147161.

Zhang YHP, Himmel ME, Mielenz JR. Outlook for cellulose improvement: screening and selection strategies. Biotechnol. Adv. 2006; 24: 452-481.

Received: January 11, 2011; Revised: August 02, 2011; Accepted: February 16, 2012. 